\title{
Matematik Öğretmenlerinin Öğrencilerin Sıfır Kavramıyla ilgili Anlayışlarına İlişkin Bilgilerinin İncelenmesi ${ }^{1}$
}

\section{Mesut Bütün²}

\author{
Naim Erdoğan ${ }^{3}$
}

\section{Type/Tür:}

Research/Araştırma

Received/Geliş Tarihi: April 30/30 Nisan 2020

Accepted/Kabul Tarihi: June

23/23 Haziran 2020

Page numbers/Sayfa No:

961-982

Corresponding

Author/Illetişimden

Sorumlu Yazar:

butunmath@gmail.com

\section{$\checkmark$ iThenticate}

This paper was checked for plagiarism using iThenticate during the preview process and before publication. / $\mathrm{Bu}$ çalışma ön inceleme sürecinde ve yayımlanmadan önce iThenticate yazılımı ile taranmiştır.

Copyright $(\subset) 2017$ by Cumhuriyet University, Faculty of Education. All rights reserved.

\section{Öz}

$\mathrm{Bu}$ çalışmanın amacı, matematik öğretmenlerinin öğrencilerin sıfır kavramı ile ilgili yaşadıkları zorlukların nedenleri hakkındaki görüşlerini belirlemek ve bu zorlukların giderilmesine yönelik çözüm önerilerini incelemektir. Araştırmada nitel durum çalışması yöntemi kullanılmıştır. Çalışmanın katılımcıları 3 ilköğretim ve 3 ortaöğretim matematik öğretmeni olmak üzere toplam 6 matematik öğretmeninden oluşmaktadır. Veriler bu öğretmenlerle gerçekleştirilen mülakatlar aracılığıyla toplanmıştır. Bu mülakatlarda sıfır kavramının ele alındığı yarı yapılandırılmış 2 senaryo tipi mülakat sorusu kullanılmıştır. Senaryoların oluşturulma sürecinde, öğrencilerin zorlandıkları ve yanılgıya düştükleri noktaları açığa çıkarmak amacıyla, sıfır kavramının farklı bağlamlarda ele alındığı bir test geliştirilmiș ve uygulanmıştır. Bu testten elde edilen verilerin analizi sonucunda öğrencilerin en çok zorlandıkları noktalar belirlenerek senaryolar yapılandırılmıştır. Araştırmanın bulguları genel olarak öğretmenlerin sıfır kavramıyla ilgili öğrenci anlayışlarını belirleyebildiklerini ve bu anlayışların nedenlerini farklı açılardan yorumlayabildiklerini fakat öğrenci zorluklarının ve kavram yanılgılarının giderilmesine yönelik çözüm önerileri geliştirirken zorlandıklarını ortaya çıkarmıştır. Bu durum matematik öğretmenlerinin öğrenciyi tanıma bilgileri bağlamında matematiği öğretme bilgilerinin yeterli düzeyde olmadığının göstergesidir. Bunların yanı sıra, ilköğretim matematik öğretmenlerinin ortaöğretim matematik öğretmenlerine göre öğrencilerin sıfır kavramılla ilgili anlayışları hakkında daha fazla ve farklı görüş beyan ettikleri ortaya çıkmıştır. Bu araştırma ile bazı matematik öğretmenlerinin matematik bilgilerinin niteliğinde de öğrencilerin zorluklarına benzer eksiklikler olduğu görülmüştür. Çalışma sonunda hem konu ile ilgili ileride yapılacak araştırmalara hem de matematik öğretmenlerinin hizmet içi eğitimine yönelik öneriler ortaya konulmuştur.

Anahtar Kelimeler: Öğretmen bilgisi, alanı öğretme bilgisi, kavram yanılgıları, sıfır kavramı, öğrenci bilgisi

\section{Suggested APA Citation/Önerilen APA Atıf Biçimi: \\ Bütün, M., \& Erdoğan, N. (2020). Matematik öğretmenlerinin öğrencilerin sıfır kavramıyla ilgili anlayışlarına ilişkin bilgilerinin incelenmesi. Cumhuriyet International Journal of Education, 9(3), 961-982. http://dx.doi.org/10.30703/cije.730314}

\footnotetext{
${ }^{1}$ Bu çalışma ikinci yazarın "Sıfır Kavramıla İlgili Öğrenci Anlayışlarının Ve Matematik Öğretmenlerinin Bu Anlayışlarla İlgili Bilgilerinin İncelenmesi" adlı yüksek lisans tezinden üretilmiştir.

2 Dr. Öğr. Üyesi, Sivas Cumhuriyet Üniversitesi, Sivas/Türkiye

Asst. Prof. Dr., Sivas Cumhuriyet University, Sivas/Turkey

e-mail: butunmath@gmail.com ORCID ID: orcid.org/ 0000-0001-7652-3674

3 Öğretmen, Milli Eğitim Bakanlığı, Sivas/Türkiye

Teacher, The Ministry of Education, Sivas/Turkey

e-mail: naimerdogan@gmail.com ORCID ID: orcid.org/0000-0002-6866-321X
} 


\title{
Mathematics Teachers' Knowledge about Students' Understanding of the Concept of Zero
}

\begin{abstract}
The aim of this study is to describe mathematics teachers' views about students' difficulties of concept of zero and to explore their propositions to overcome these difficulties. Qualitative case study method was used in the research. The participants of the study consisted of 6 mathematics teachers, 3 middle school and 3 high school mathematics teachers. The data were collected through interviews. In these interviews, 2 semi-structured scenario type interview questions were used, which addressed the concept of zero. In the process of creating the scenarios, in order to reveal the points that students have difficulties and misunderstandings, a test in which the concept of zero was handled in different contexts was developed and applied to students. As a result of the analysis of the data obtained from this test, scenarios were structured. Depending on the interviews conducted with the teachers, it was found that the teachers were able to identify the misconceptions and causes that were generally found in the students, but they had difficulties in developing any solution suggestions for these misconceptions. This is an indication that mathematics teachers do not fully recognize the student and therefore the pedagogical content knowledge of teachers is not sufficient. This study revealed that middle school mathematics teachers expressed more and different views about students' understanding of the concept of zero compared to high school mathematics teachers. As a result, it was determined that some mathematics teachers had inadequate quality of mathematics knowledge, similar to the difficulties experienced by students. At the end of the study, suggestions for both future research and in-service training of mathematics teachers were made.
\end{abstract}

Keywords: Teachers' knowledge, pedagogical content knowledge, misconceptions, concept of zero, knowledge about students

\section{Giriş}

Çocuklarda okul hayatından önce gelişmeye başlayan sayı kavramı, ilerleyen yıllardaki matematik öğrenme deneyimlerinin temelini oluşturmaktadır. Sayma süreci ve sayı kavramı; sınıflandırma, sıralama, karşılaştırma, birebir eşleme gibi temel matematiksel becerileri içermesinin yanı sıra, işlem yapma becerisinin de ön koşuludur (Kumtepe, 2011). Çocuklarda sayı kavramının gelişiminde diğer sayılardan farklı özellikleri olan sıfır sayısının önemi büyüktür. Cockburn ve Parslow-Williams (2008, s.11) günlük yaşamda doğrudan bir karşılı̆̆1 bulunmadı̆̆ından sıfırın çocukların karşılaştı̆̆ı ilk "matematiksel" sayı olduğunu, bu nedenle de çocuklar için özel ve zorlayıcı bir yönünün olduğunu belirtmişlerdir. Sıfır sayısı, "hiçlik", “yokluk”, "boşluk” ve "nötr” gibi kavramlar ile ilişkilendirildiği için, bir sayı olmasının yanında aynı zamanda karmaşık bir kavramdır. Bu karmaşıklık, kavramın tarihsel gelişim sürecinden de yansımaktadır. Kavramın tarihsel gelişim sürecinde geçtiği aşamalar takip edildiğinde, özellikle sıfırın diğer sayılardan farklı özellikleri ve işlemlerde kullanımı gibi alanlarda çeşitli zorluklarla karşılaşıldığı ifade edilmektedir (Boyer, 1944; Ifrah, 1985; Kaplan, 1999). Yine eğitim araştırmalarında sıfır kavramıyla ilgili öğrencilerin matematiksel zorluklarının büyük bir kısmının da aynı alanlarda yaşandığı ifade edilmektedir (Henry, 1969; Anthony ve Walshaw, 2004; Levenson, Tsamir ve Tirosh, 2007). Öğrencilerin matematiksel zorluklarının nedenlerini anlama ve bu zorlukların aşılmasına yönelik çözüm önerileri geliştirme görevi ve sorumluluğu temelde öğretmenlerindir. Bu nedenle öğretmenlerin niteliği, öğretimin niteliğini doğrudan etkilemektedir (Darling-Hammond, 2000). 
Geçmişten günümüze öğretmenlerin niteliklerinin en önemli göstergesinin bilgileri olduğu kabul edilmiştir. Öğretmen bilgisinin çok boyutlu karmaşık yapısının yeterince algılanmadı̆̆ 1 ve öğretmenliğin uzmanlık gerektiren profesyonel bir meslek olarak değerlendirilmediği zamanlarda, öğretilecek konuyu bilmenin öğretme için yeterli olabileceği düşünülmüştür (Bütün, 2012). Fakat Shulman'ın $(1986,1987)$ öncülüğünü yaptığı yakın zamandaki birçok çalışmada alan bilgisinin etkili öğretim için tek başına yeterli olmadığı vurgulanmış, yeni bir kavram ve terim olarak öğretmenin alanı öğretme bilgisinin (pedagogical content knowledge) önemi ön plana çıkarılmıştır. Shulman'a (1987) göre alanı öğretme bilgisi, alan bilgisi ile pedagojik bilginin bütünleştirilmesi sonucu yapılandırılan bir bilgidir. Bu bilgi, öğretmenin alan bilgisini öğrencilerin anlamasına yardımcı olacak şekilde dönüştürüp kullanabilmesi, konu ve kavramlarla ilgili öğrencilerin önbilgi, zorluk ve yanılgılarını bilmesi ve bu bilgiyi öğretim yöntemlerine yansıtabilmesini içermektedir (Bütün, 2012; Grosmann, 1990; Hill, Ball ve Schilling, 2008; Marks, 1990). Alan yazında alanı öğretme bilgisinin farklı boyutları tanımlanmakla birlikte, bu boyutlar arasında öğrenci bilgisi nerdeyse tüm kavramsal çerçevelerde yer alan önemli bir bilgi öğesi olarak dikkat çekmektedir (Jing-Jing, 2014). Bu nedenle öğretmenlerin matematiksel kavramlarla ilgili öğrenci bilgileri, onların alanı öğretme bilgilerinin niteliklerinin güçlü bir göstergesi olarak değerlendirilmektedir.

Öğrenci bilgisi, öğretmenlerin bir kavram ya da konuyla ilgili öğrencilerin ön bilgileri, kavram yanılgıları, yaşadıkları zorluklar ve öğrenme yöntemleri hakkındaki bilgisidir (An, 2004). Bu bilgi öğretmenin sınıf içeresinde aldığı öğretim kararları üzerinde oldukça etkilidir (Tanışlı, 2013). Öğrencisinin düşüncesini anlama çabasında olan bir öğretmen öğrencisine değer verir, onun fikirlerini dikkate alır ve öğretimi de bu fikirler üzerine inşa eder. Sınıf içerisindeki tartışmalarda hangi öğrenciye ne zaman ve ne şekilde söz vereceğini, hangi soruları yönelteceğini, hatalı düşünce ve anlayışları nasıl düzelteceğini bilir; yani bunlarla ilgili bir takım senaryoları vardır. Bu senaryoların geliştirilmesi ve uygulanması ise bazı konu ve kavramlar için daha zor olabilmektedir. Özellikle öğrenilmesi ve öğretilmesinde güçlük yaşanan kavram ve konularda, hem bu güçlüklerin nedenlerinin tespit edilmesi hem de bunların aşılmasına yönelik çözüm önerilerinin üretilmesi üst düzey bir alanı öğretme bilgisi gerektirmektedir. Bu bağlamda sıfır, öğretmenlerin öğrenci bilgileri bağlamında alanı öğretme bilgilerinin incelenmesi için uygun bir kavram olarak değerlendirilebilir.

Sıfır kavramı ile ilgili öğrencilerin yaşadıkları zorluklar çeşitlilik göstermektedir. Alan yazında, sıfırın "hiçlikle" özdeşleştirildiği için bir sayı olarak kabul edilmemesi, diğer sayılara ait bir takım özelliklerin sıfır için geçerli olmadığının düşünülmesi (örneğin, teklik-çiftlik) ya da bu özelliklerin aşırı genellenmesi (örneğin, sayının işareti), başka sayıların ifade edilmesinde sıfırın rolünün anlaşılamaması ve sıfırın aritmetik işlemlerde yer aldığında anlamlandırılamaması gibi öğrenci zorlukları sıralanmaktadır (Altoğ, 2016; Cockburn ve Parslow-Williams, 2008; İşgüden, 2008; Sharma, 1993). Öğretmen ve öğretmen adayları ile yapılan çalışmalarda da benzer zorluklar rapor edilmiştir. Örneğin, Bütün (2012) 7/0 işleminin sonucunu merak eden ve 0'a bölmeyi anlamaya çalışan bir öğrenciye ilişkin senaryoya yönelik öğretmen adaylarının yaptıkları açıklamaları analiz etmiş ve bu adayların dönemsel olarak gelişimlerini incelemiştir. 
İlk uygulamada, adayların birçoğunun 0'a bölmeyi anlatırken; "tanımsız", "bölünemez", "kuralı budur", "bu bir kabuldür" şeklinde söylemler kullanmanın ötesinde öğrenciye yönelik kavramsal bir açıklama yapamadıkları belirlenmiştir. Yine sonraki uygulamalarda öğretmen adaylarının bölme işlemi için sundukları gerekçeler; sıfır, tanımsızlık, belirsizlik ve sonsuzluk gibi önemli matematiksel kavramlar hakkındaki anlayışlarının yeterince ilişkilendirilmediğini ve iyi yapılanmadığını ortaya koymuştur. Bu açıklamalarda adaylardan bazıları, sıfırı "hiçlik" ya da "olmayan şey" ifadeleri ile nitelendirerek bölmenin yapılamayacağını ifade ederken, diğer bazıları tanımsızlığı sonsuzlukla özdeşleştirmiş, yine bir kısım aday ise gerekçelendirmelerinde belirsizlik ve sonsuzluk terimlerini birbirleri yerine kullanmışlardır. Alan yazında, benzer yöndeki öğretmen/öğretmen adayı anlayışları başka çalışmalarda da rapor edilmiştir (Quinn, Lamberg ve Perrin, 2008; Crespo ve Nicol, 2006; Tsamir, Sheffer ve Tirosh, 2000; Tsamir ve Tirosh, 2002; Cankoy, 2010; Karakuş, 2017). Bu çalışmaların odak noktaları ve elde ettikleri sonuçlar, çoğunlukla öğretmenlerin/öğretmen adaylarının sıfır kavramı ile ilgili matematik bilgilerinin nitelikleri üzerinedir. Önceden de değinildiği gibi alan bilgisi öğretmenin bilgisinin niteliğinin açıklanmasında tek başına yeterli değildir. Öğretmenlerin sıfır kavramı ile ilgili öğrencilerin anlayışları hakkındaki bilgilerinin de incelenmesi gerekmektedir. Böylece, öğretmenlerin alan bilgilerinin yanı sıra alanı öğretme bilgilerinin niteliği ile ilgili sonuçlar da ortaya çıkarabilecektir. Ayrıca, elde edilecek bu sonuçlar, hem matematik öğretmeni yetiştirmedeki yaklaşımların değerlendirilmesine hem de kavramin öğretimi ile ilgili kaynak ve materyallerin tekrar gözden geçirilmesine yardımcı olacaktır.

$\mathrm{Bu}$ çalışmanın amacı, matematik öğretmenlerinin sıfır kavramı ile ilgili öğrencilerin yaşadıkları zorlukların nedenleri hakkındaki bilgilerini ve bu zorlukların giderilmesine yönelik çözüm önerilerini incelemektir.

\section{Yöntem}

$\mathrm{Bu}$ araştırmada nitel durum çalışması yöntemi kullanılmıştır. Nitel durum çalışması, özellikle sınırlı bir bağlamda ve az sayıdaki katılımcılla, bu katılımcıların anlayışlarının derinlemesine incelenmesi ve betimlenmesi söz konusu olduğunda tercih edilen bir yöntemdir (Creswell, 2013).

\section{Çalışma Grubu}

$\mathrm{Bu}$ araştırmada 3 ilköğretim ve 3 ortaöğretim matematik öğretmeni olmak üzere toplam 6 matematik öğretmeni ile çalışılmıştır. Öğretmenlerin tamamı bu çalışmanın ikinci yazarı konumundaki öğretmen olan araştırmacı ile aynı ilçede öğretmenlik yapmaktadır. Ortaöğretim matematik öğretmenleri ise bu araştırmacı ile aynı okulda görev yapmaktadırlar. Öğretmen bilgisinin incelendiği çalışmalarda öğretmenler ile araştırmacı arasında belli düzeyde samimiyet oluşturulması ve karşılıklı güven tesis edilmesi gerektiği ifade edilmektedir (Bütün, 2011). Bütün (2011), bu şekilde bir samimiyet ve güven ortamının eksik olduğu durumlarda, öğretmenlerin kendilerine yöneltilen sorulara açıklama yapmaya yanaşmadıkları ve cevaplarken tedirgin olduklarını belirtmektedir. Bu nedenle, çalışma grubu belirlenirken araştırmacının yakın çevresindeki araştırmaya katılmaya gönüllü matematik öğretmenleri arasından seçim yapılmıştır. Yine bu seçim yapılırken, çeşitliliği sağlamak amacıyla hem ilköğretim hem de ortaöğretim öğretmenlerinin eşit sayıda olmasına dikkat 
edilmiştir. Çalışmada, araştırmaya katılan öğretmenlerin isimleri gizli tutulmuş olup, temsili olarak ilköğretim matematik öğretmenlerine Turgut, Mehtap ve Zeliha; ortaöğretim matematik öğretmenlerine ise Gül, Emre ve Ahmet isimleri verilmiştir. Öğretmenler ve mesleki deneyimleri aşağıdaki Tablo 1'de sunulmuştur.

Tablo 1

Çalışmaya Katılan Öğretmenlerin Mesleki Deneyim Süreleri ve Branşlar

\begin{tabular}{lcccccc}
\hline Branş & \multicolumn{3}{c}{ İlköğretim } & \multicolumn{3}{c}{ Ortaöğretim } \\
\hline $\begin{array}{l}\text { Öğretmenler } \\
\begin{array}{l}\text { Hizmet süreleri } \\
\text { (yıl) }\end{array}\end{array}$ & Turgut & Mehtap & Zeliha & Gül & Emre & Ahmet \\
\hline
\end{tabular}

\section{Veri Toplama Araçları}

$\mathrm{Bu}$ araştırmada sıfır kavramı ile ilgili iki senaryo tipi mülakat sorusu kullanılmıştır. $\mathrm{Bu}$ soruların ilkinde, sıfırı tek ya da çift sayı olarak kabul etmeyen bir grup öğrencinin görüşü, diğerinde ise sıfır sayısını içeren bölme işleminde bir öğrencinin hatalı çözümü ele alınmıştır. Mülakatlarda ilk aşamada öğretmenlerden senaryolardaki öğrencilerin nasıl/neden böyle düşünmüş olabileceklerini açıklamaları istenmiştir. İkinci aşamada ise öğretmenler bu düşüncelerin sahibi olan öğrenciye/öğrencilere nasıl dönüt vereceklerini ve bu türdeki öğrenci zorluklarının nasıl üstesinden gelebileceklerini açıklamışlardır. Mülakatlarda kullanılan senaryoların oluşturulması aşamasında, hem ortaokul hem de lise öğrencilerine (96 ortaokul, 108 lise öğrencisi) sıfır kavramının ele alındığ 10 sorudan oluşan bir test uygulanmıştır. Bu testteki sorular hazırlanırken, sıfır kavramıyla ilgili hangi boyutlara odaklanılacağını belirleme bağlamında alan yazındaki farklı kaynaklardan (Altoğ, 2016; Bütün, 2012; Cankoy, 2010; Sharma, 1993; Tsamir ve Sheffer, 2000), soruların şekilsel özelliklerinin ve ifade edilme biçimlerinin uygunluğunu sağlama bağlamında ise matematik eğitimi alanında uzman iki akademisyenin görüşlerinden faydalanılmıştır. Sorularda; sıfırın tekliği/çiftliğinin belirlenmesi, sıfırın diğer sayıların ifade edilmesindeki rolü, sıfırı içeren aritmetik işlemler ve sıfır sayısı ile ilgili bazı önermelerin doğruluğunun değerlendirilmesi gibi boyutlar işlenmiştir. Örneğin, bu testteki sorulardan birinde öğrencilerden sıfır sayısının tek, çift ya da ne tek ne de çift olduğuna ilişkin seçeneklerden birini işaretlemelerini ve gerekçelerini yazmaları istenmiştir. Yine diğer bir soruda, öğrencilerden "bir sayıyı 10 ile çarpmak demek sayının yanına 0 (sıfır) yazmak demektir" ifadesine katılıp katılmadıklarını nedeniyle birlikte ifade etmeleri istenmiştir. Senaryolar, bu testte verilen cevapların analiz edilmesi sonucu ortaya çıkmış ve bir matematik eğitimi araştırmacısının görüşleri 1şı̆̆ında son halini almıştır. Bu çalışmada odaklanılan iki senaryonun seçiminde ise sıfır kavramı ile ilgili öğrencilerin cevaplamakta daha çok zorlandıkları ve düşünme biçimlerinde farklılıkların olduğu durumlar dikkate alınmıştır. Böylece, öğretmenlerin mülakatlarda bu senaryolara ilişkin yorumlarının öğrenciyi tanıma bilgileri bağlamında alanı öğretme bilgilerinin niteliklerini büyük ölçüde yansıtacağı düşünülmüştür. 


\section{Verilerin Analizi}

Veri analizi iki aşamada gerçekleşmiştir. İlk aşamada, araştırma sürecinde öğretmenlerden elde edilen tüm ses kayıtları yazıya dökülmüş ve bilgisayar ortamına aktarılmıştır. İkinci aşamada ise bu veriler öğrencilerin yanılgı içeren anlayışlarının olası nedenleri ve öğretmenlerin çözüm önerilerinin neler olduğu bağlamında incelenerek benzerlik ve farklılıklarına göre yorumlanmış, sınıflandırılmış ve nihayetinde belirli temalar ortaya çıkarılmıştır. Temaların oluşturulma sürecinde, iki araştırmacı bağımsız olarak veri setini incelemiş ve sonrasında bir araya gelerek uzlaşmaya varmışlardır. Yine mülakat verilerinin yorumlanmış ve temalara ayırılmış ilk versiyonu, yani çalışmanın ön bulguları katılımcı öğretmenlere sunularak ulaşılan bulgular teyit edilmiştir. Araştırmanın bulguları sunulurken, her bir senaryo için bu temalarda kaç öğretmenin yer aldığını gösteren tablolar düzenlenmiş ve gerektiğinde de ortaya çıkan bu temalarla ilgili öğretmenlerin söylemlerini yansıtan doğrudan alıntılar kullanılmıştır. Çalışmada her bir öğretmen bir durum olarak ele alındığ1 için, bütünlüğün bozulmaması adına öğretmenlerden elde edilen bulgular sıra ile sunulmuş ve yorumlanmıştır. Bulgularda mülakatı yürüten araştırmacı A harfi ile gösterilmiş, öğretmenler için ise yukarıda aktarılan takma isimler kullanılmıştır.

\section{Bulgular}

Bu bölümde öğretmenlerin öğrenci anlayışları ile ilgili bilgilerine ait bulgular her bir senaryo için ayrı başlıklar altında aşağıda sunulmuştur.

\section{Senaryo 1}

Bu senaryoda ilk aşamada öğretmenlere, bazı öğrencilerin sıfırı tek ya da çift sayı olarak kabul etmedikleri düşüncesi yöneltilerek bu düşüncenin nedenini yorumlamaları istenmiştir. Devamında ise bu düşünceye sahip bir öğrenciye verecekleri dönütün ne olabileceği sorusu yöneltilmiştir. Elde edilen veriler incelendiğinde, üç ilköğretim matematik öğretmeninin ve iki ortaöğretim matematik öğretmeninin öğrencilerin düşüncelerinin nedenleri hakkında fikir beyanında bulunduğu ortaya çıkmıştır. Diğer öğretmen ise öğrencilerin neden böyle düşündükleri konusunda fikir yürütememiştir. Araştırmacının soruyu derinleştirmesi üzerine bu öğretmen; ortaokulda matematik öğretmenlerinin çift sayıları anlatırken 2'den başlamış olabileceğini belirtmiştir.

Öğretmenlerle yapilan mülakatlardan hareketle, öğretmenlerin öğrenci düşüncesinin olası nedenleri ve çözüm önerileri ile ilgili görüşleri aşağıda Tablo 2' de özetlenmiştir. Tablodaki frekans değerlerinden de yansıdığı gibi, bir öğretmenden elde edilen farklı cevaplar farklı satırlarda yer alabilmekte ve bir öğretmen birden fazla neden ve çözüm önerisi belirtebilmektedir. 
Tablo 2

Senaryo 1'de Öğretmenlere Göre Öğrenci Düşüncesinin Olası Nedenleri ve Çözüm Önerileri

\begin{tabular}{|c|c|c|c|}
\hline $\mathrm{f}$ & $\begin{array}{l}\text { Öğrenci Düşüncesinin } \\
\text { Olası Nedenleri }\end{array}$ & $\mathrm{f}$ & Çözüm Önerileri \\
\hline 4 & $\begin{array}{l}\text { En küçük çift sayının } 2 \\
\text { olduğunu düşünmek }\end{array}$ & 3 & $\begin{array}{l}\text { 2'den bir önceki çift } \\
\text { sayının keşfettirilmesi }\end{array}$ \\
\hline 1 & $\begin{array}{l}\text { Sıfırın negatiflik ve } \\
\text { pozitifliği ile teklik ve } \\
\text { çiftliğini karıştırmak }\end{array}$ & & \\
\hline 1 & $\begin{array}{l}\text { Sifır hem 2'ye, hem } \\
\text { 3'e, hem } 4^{\prime} \mathrm{e} \text { vs. tam } \\
\text { bölündüğü için }\end{array}$ & 1 & $\begin{array}{l}\text { Birler basamağı sıfır } \\
\text { olan sayıların } \\
\text { çiftliğinin } \\
\text { sorgulatılması }\end{array}$ \\
\hline 1 & $\begin{array}{l}\text { Öğrenci } 2 \mathrm{n} \text { veya } 2 \mathrm{n}+1 \\
\text { kalıbını } \\
\text { olması }\end{array}$ & 1 & $\begin{array}{l}2 \mathrm{n} \text { kalıbının } \\
\text { oluşturulması ve } \mathrm{n} \\
\text { yerine tamsayı } \\
\text { değerlerinin verilmesi }\end{array}$ \\
\hline 1 & $\begin{array}{l}\text { Tek ve çift sayıların } \\
\text { ardışık olduğunun } \\
\text { bilinmemesi }\end{array}$ & & \\
\hline
\end{tabular}

Tablo 2' de öğretmenlerin bazı olası nedenleri ve çözüm önerilerini daha çok tercih ettikleri görülmektedir. Olası nedenler konusunda 6 öğretmenden toplam 5 farklı cevap alınırken, çözüm önerileri konusunda ise 3 cevap alınmıştır. Bu da öğretmenlerin çocukların düşüncelerinin nedenleri ile ilgili farkındalık düzeylerinin çözüm önerisi geliştirme düzeylerine göre daha ileride olduğunu göstermektedir. Aşağıda her bir öğretmenle Senaryo 1 hakkında yapılan mülakatlardan örnek kesitler sunulmuş ve yorumlanmıştır.

Turgut ve araştırmacı arasında bu senaryo ile ilgili geçen konuşmada Turgut; "Öğrenciler en küçük çift sayıyı 2 olarak kabul ediyor olabilirler. Bu nedenle ikiye bölünebiliyorsa çifttir bölünemiyorsa tektir diyor olabilirler." şeklinde bir ifade kullanmıştır. Ardından meslek hayatında böyle öğrencilere pek denk gelmediğini belirten Turgut; "İşin açı̆̆ı ben çok denk gelmedim ama şöyle bir durum oluyor; sıfır tek midir çift midir diye soru yönelttiğimde çifttir diyorlar fakat çift sayılarn söyleyin dediğimde 2 den başlıyorlar." demiştir. Bunun üzerine araştırmac1; "Anladım hocam. Hocam bu maddeyle ilgili ikinci sorumuz şöyle; siz sıfırı tek ya da çift kabul etmeyen bir öğrenciye denk gelirseniz ona nasıl bir dönüt verirdiniz?" diye sormuş ve Turgut ise 2'nin çift bir sayı olmasından hareketle; "Belki şöyle anlatmaya çalışırım; çocuk ikinin çift olduğunu, sonrasında 4,6,8 vs. geldiğinin farkında. Yani ikişer ikişer artarak gittiğini bildiğine göre 2 
den bir önce hangi çift sayı olduğunu sorarım. Böylece sıfırın da çift sayı olduğunu görmüş olur." demiştir.

$\mathrm{Bu}$ söylemler, Turgut öğretmenin öğrencilerin düşüncelerinin nedenleri hakkında fikir sahibi olduğunu, ayrıca öğrencilerdeki bu düşüncenin nasıl düzeltilebileceği ile ilgili çözüm önerilerine de sahip olduğunu göstermektedir.

Mehtap ise öğrencilerin sıfır sayısının pozitif veya negatif olmayışını tek ya da çift değildir şeklinde genellediklerini düşündüğünü belirterek; "Sıfır sayısını pozitif ya da negatif sayılara dâhil etmiyoruz, bence bunu öğrenci karıştırıyor olabilir. Yani 0 pozitif ya da negatif değildir diyeceğine tek ya da çift değildir diyor olabilir." demiştir. Bunun üzerine araştırmacı, öğrencilerin böyle düşünmelerinin farklı nedenlerinin neler olabileceğini sorması üzerine, Mehtap; “Şöyle düşünmüş olabilirler belki; sayma sayılar birden başladı̆̆ için sıfırı hiç saymıyor da olabilirler." demiştir. Araştırmacı ve öğretmen arasında ilerleyen süreçte ise şöyle bir konuşma geçmiştir.

A: Şunu mu demek istiyorsunuz hocam; öğrenci ilk olarak 1 sayısıyla karşılaşır. Sıfırla tanışması biraz zaman alır. O yüzden aklına ilk 1 gelir.

Mehtap: Evet, bence öyle. Bu yüzden de sıfıra sayı gözüyle bile bakmayan öğrenciler vardır. Bunun üzerine araştırmacl; "Peki, size böyle bir iddiada bulunsa öğrenci, sıfir ne tektir ne de çifttir dese ona nasıl bir dönüt verirdiniz?" diyerek öğretmenin çözüm önerisi sormuştur. Mehtap ise birler basmağı sıfır olan sayıların çift olmasını örnek göstereceğini belirterek; "Peki 20 sayısı nedir diye sorardım, ya da 30, 40..." demiştir. Araştırmacı öğretmenin söylemek istediğinden emin olmak için birler basamağında sıfır olduğu için mi böyle dönüt vereceğini sormuştur. Mehtap ise; "Aynen, 20 sayısına öğrenci çifttir diyecektir. Çünkü normalde bilmesi gerekiyor bunu. Ben de o zaman derim ki; bak burada sıfirn çift kabul ettiğin için 20'ye de çift diyorsun. Demek ki sıfır da çift bir sayıymış." demiştir.

Yukarıdaki kesitlerden de anlaşılacağı üzere, Mehtap'ın öğrencilerinin düşünceleri ile ilgili farkındalığının bulunduğu, bunu birkaç olası nedenle açıklayabildiği görülmektedir. Bununla birlikte Mehtap öğretmenin öğrencilerine verebileceği dönütler sorulduğunda, yaptı̆̆ı açıllamalardan çözüm önerilerine sahip olduğu da anlaşılmaktadır.

Zeliha ile araştırmacı arasında geçen konuşmada ise Zeliha, öğrencilerin ezber bilgi ile hareket ettiklerini ve konunun mantığını pek sorgulamadıklarını belirterek; "Öğrenciler daha çok ezbere bilgi ile hareket ediyorlar. İşin mantığını, nereden geldiğini çok fazla yorumlamıyorlar, sorgulamıyorlar ve soyut olarak öğreniyorlar." demiştir. Araştırmacının "soyut öğrenme" ifadesini biraz daha açmasını istemesi üzerine Zeliha; "Yani 2,4... gibi sayılar daha somut bence, sıfır soyut bir kavram sonuçta." demiştir. Zeliha'nın farklı bir olası neden belirtemeyeceği anlaşılınca araştırmacı tarafından öğretmenin vereceği dönüt sorulmuş ve araştırmacı ile öğretmen arasında şu konuşma geçmiştir;

A: Anladım hocam. Öğrenci bu yüzden zorlanıyor diyorsunuz. Peki, size böyle bir şey diyen bir öğrencinize nasıl bir dönüt verirdiniz?

Zeliha: Bilemiyorum nasıl cevap verirdim. Yardımcı olur musunuz?

Öğretmenin heyecanlı olabileceği ve sağlıklı düşünememiş olabileceği düşünülerek kendi talebi üzerine bazı ipuçları verilmiştir; "Hocam mesela 2 sayısı, 4 sayısı, 6 sayısı hep çift ve ...". Öğretmen yeterli ipucunu almış olmalı ki araştırmacı sözünü bitirmeden; "Örüntü oluşturmalarm să̆layabilirim, evet. Yani 2'den başlayarak ikişer ikişer artırıp çift sayıları elde ederlerken, geri giderek de yine tek sayıları bulabileceğini fark 
ettiririm. Nihayetinde 2'den bir önceki çift sayını sıfir olduğunu görecektir öğrenci." demiştir. Araştırmacı diğer soruya geçecek iken Zeliha; "Yalnız burada şuna da dikkat etmek lazım. Öğrenci sıfıra gelince durmalı, negatif sayılara girmemeli." demiştir. Zeliha' nın cevabından emin olmak isteyen araştırmac1; "Negatif sayılarda teklik çiftlik yoktur diyorsunuz yani?" diye sormuştur. Bunun üzerine; "Evet. Yoksa hata yapmış olur ögrenci." demiştir.

Bu söylemlerden de anlaşıldığı gibi Zeliha öğretmen ilk etapta öğrencilerin neden bu düşünceye sahip olabilecekleri konusunda fikir beyan edememiş, öğrencilerin düşünmeden, mantık yürütmeden ezbere cevap verdiklerini iddia etmiştir. Zeliha ayrıca öğrencilere vereceği dönüt konusunda da sıkıntı yaşamış ve ilk aşamada cevap verememiştir. Bunun üzerine araştırmacıdan ipucu istemiş ve bir çözüm önerisinde bulunmuştur. Ayrıca, Zeliha öğretmen negatif sayılarda teklik ve çiftlik kavramlarının tanımlı olmadığını, bu kavramların sadece doğal sayılarda sorgulanması gerektiğini de iddia ederek kendi hatalı matematik bilgisini de yansitmıştır.

Gül ise sıfırın hem 2'ye hem 3'e hem 4'e tam bölünebiliyor olmasından dolayı öğrencilerin sıfırı ne tek ne de çift olarak kabul ettiklerini belirtmiştir. Bu konuda sözlerini; "Hocam biz ögrrenciye çift sayılar anlatırken ikiye tam bölünebilen sayılar çift sayılardır diyoruz. Düşündüğ̈̈müz zaman sıfır sayısı hem 2'ye hem 3'e hem 4'e kalansız bölünüyor. Öğrenci bence bu kuralı karıştırmış olmalı ki sıfırı çift sayılara da tek sayılara da dâhil etmiyor." diyerek belirten Gül; araştırmacının bu konuda başka fikri olup olmadığını sorması üzerine; " $2 n$ ya da $2 n+1$ kuralına uydurmaya çalışsa belki anlayacak doğrusunu. Ya da daha genel düşünseler mesela; tekten önceki sayı çift, çiftten önceki sayı tek olduğunu görseler sıfırın çift sayı olduğunu daha iyi anlayacaklar bence." demiştir. Gül'ün başka bir fikir beyan etmeyeceğini anlayan araştırmacı Gül'e bu konuda öğrencilerine nasıl bir dönüt verebileceğini sormuştur. Gül ise öğrencilerin çift sayıları ifade ederken kullanılan 2n kalıbını iyi anlamaları gerektiğini belirterek; “ $2 n$ kalıbını oturtmaya çalışırdım. Sonra n yerine sayılar vererek elde ettiği tüm sayıların çift olduğunu görmesini sağlarım ve son olarak n yerine sifır sayısını vermesini isterim. Böylece öğrenci sıfırı elde edecek ve sıfırın da bir çift sayı olduğunu kabul edecektir." demiştir. Araştırmacı Gül'ün öğrencilere yönelik başka bir dönütünün olup olmadığını sorması üzerine Gül; "Şöyle diyebilirim, mesela ardışık çift sayılar arasında hep 2 fark olduğunu keşfetmesini să̆larım önce. Sonrasında da 2'den bir önceki çift sayının sıfır olduğunu görmesini sağlarm." demiştir.

Bu bulgular, Gül'ün öğrencilerin neden sıfırı tek ya da çift kabul etmedikleri konusunda olası iki sebep belirttiğini ve onların yanılgılarını gidermek için ise yine iki farklı çözüm önerisinde bulunabildiğini göstermektedir.

Emre ile yapılan mülakatta öğrencilerin sıfırı neden tek ya da çift kabul etmemiş olabileceklerinin sorulması üzerine, Emre kendi meslek hayatında bazı öğrencilerin negatif sayılarda teklik ve çiftlik kavramlarının geçerli olduğunu bilmediklerini gördüğünü belirtmiştir. Ardından sıfırın tek ya da çift kabul edilmemesinin sebebinin ortaokulda aldıkları eğitimle alakalı olduğunu belirten Emre; "Ben hatta bazı öğrencilerin negatif sayılarda teklik çiftlik kavramından da bihaber olduğuna şahit oldum. Sifırı tek ya da çift sayı kabul etmemeleri sanırım ortaokulla alakah. Yani ortaokuldan kalan bir anlam kargaşası sanki. Kavramı tam öğrenmemiş olabilir." demiştir. Bunun üzerine araştırmacı ortaokulda nelerin eksik ya da hatalı öğrenilmiş olabileceğini sormuştur. Araştırmacı sorusunun daha iyi anlaşılması için; “Ne olmuş 
olabilir peki hocam? Yani ortaokulda bu öğrenci neyi eksik öğrenmiş ya da öğretmen ne demiş de çocuk böyle anlamış olabilir sizce?" demiştir. Bunun üzerine Emre; "Öğretmen tek sayıları sayarken $1,3,5,7 \ldots$; çift sayıları sayarken de $2,4,6, \ldots$ diye başlamış ve sıfırı ihmal etmiş olabilir." diyerek ortaokuldaki matematik öğretmenlerinin vermiş olabilecekleri hatalı ya da ihmal edilmiş olası bilgileri belirtmiştir. Araştırmacının Emre'ye öğrencilerine bu konuda vereceği dönütü sorması üzerine Emre; "Bunun bir kural olduğunu söylerim. Sıfır çifttir derim. Ama nasıl anlatırım ben de bilmiyorum açıkçası." demiştir.

Yukarıdaki ifadeler, Emre öğretmenin öğrencilerin düşüncelerinin altında yatan nedeni ortaokulda aldıkları matematik eğitimine bağladığını göstermektedir. Ayrıca, öğretmen bu şekilde zorluk yaşayan öğrencilere yönelik etkili bir çözüm önerisi geliştirememiş, sıfırın çift bir sayı olduğu bilgisini öğrencilerine bir kural olarak aktaracağını ifade etmiştir.

Ahmet ile araştırmacı arasında geçen konuşmada ise Ahmet, öğrencilerin sayma yaparken sıfırı ihmal etmelerine değinerek; "Sanki şey gibi geldi bana; öğrenci sayarken 1,2,3,4,5... diye sayıyor. Yani bir tek bir çift gidiyor. Illk tek sayıyı 1, ilk çift sayıyı da 2 kabul ediyorlar, öyle olunca da sıfir akıllarına hiç gelmiyor bence. Sıfirn sonradan öğreniyoruz ya hani, o yüzden de böyle düşünüyor olabilirler bence." demiştir. Bunun üzerine araştırmac1, "sonradan öğrenme" ifadesinde ne demek istediğini sormuş ve Ahmet; "Yani önce 1 tane, 2 tane vs. ögrretiliyor. Yokluk ise sonraları karşılarına çıkıyor. Öyle olduğu için belki oradan sıfıra çift diye geri dönüş yapamıyor olabilirler." demiştir. Ahmet'e öğrencilerine vereceği dönüt sorulduğunda ise öğrencilere sıfırın bir çift sayı olduğunu belirteceğini söylemiştir. Ancak bunu söylemenin yetersiz olduğunun farkında olan Ahmet; "Sıfırın çift sayı olduğunu söylerim ama neden çift olduğunu ispatlamak lazım tabi." demiştir. Bir süre düşünen Ahmet; "Aklıma bir şey gelmedi valla." diyerek öğrencilere nasıl bir açıklama yapacağını bilmediğini belirtmiştir.

$\mathrm{Bu}$ diyaloglardan da anlaşılacağı üzere, Ahmet öğretmen öğrencilerinin düşüncelerinin altında yatan sebep hakkında olası bir neden belirtirken bu düşüncenin düzeltilmesi için herhangi bir çözüm önerisi belirtememiştir.

\section{Senaryo 2}

$\mathrm{Bu}$ mülakat sorusunda öğretmenlere, kesirlerde bölme işlemini Şekil 1'deki gibi yapan öğrencinin hatalı çözüm yolu gösterilmiş ve bu durumu yorumlamaları istenmiştir.

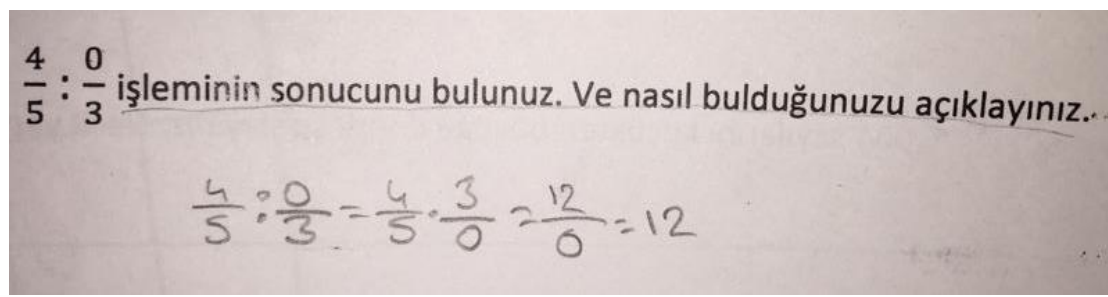

Şekil 1. Öğrencinin hatalı çözümü

Yapılan görüşmelerden elde edilen veriler incelendiğinde, üç ilköğretim matematik öğretmeninden ikisinin ve üç ortaöğretim matematik öğretmeninden birinin aynı cevabı verdiği ortaya çıkmıştır. Bu öğretmenler, öğrencilerin 12'yi sıfıra bölerken 12 sayısına hiç dokunmadıklarını, dolayısıyla 12 sayısının olduğu gibi 
kaldığını düşünmüş olabileceklerini ifade etmişlerdir. Diğer ilköğretim matematik öğretmeni ise öğrencilerin çarpmada etkisiz eleman olan 1 sayısı ile 0 sayısını karıştırmış olabileceğini ifade etmiştir. Ortaöğretim matematik öğretmenlerinden diğer ikisi ise öğrencilerin düşünceleri ile ilgili fikir beyanında bulunamamışlardır. $\mathrm{Bu}$ iki öğretmenden birisi hiç cevap verememiş, diğeri ise öğrencilerin bu işlemi yaparken mantık yürütmediğini ve cevabı ezbere verdiklerini söylemiştir. Öğretmenlerin Senaryo 2'ye yönelik cevaplarını yansıtan tablo aşağıda sunulmuştur.

Tablo 3

Senaryo 2'de Öğretmenlere Göre Öğrenci Düşüncesinin Olası Nedenleri ve Çözüm Önerileri

\begin{tabular}{llll}
\hline $\mathrm{f}$ & $\begin{array}{l}\text { Öğrenci Düşüncesinin } \\
\text { Olası Nedenler }\end{array}$ & Çözüm Önerileri \\
\hline & $\begin{array}{l}\text { Öğrencilerin } 12 \text { sayısına } \\
\text { hiç dokunmadılarını } \\
\text { düşünmeleri. }\end{array}$ & 1 & $\begin{array}{l}\text { Belirli sayıda nesnenin sifır kişiye } \\
\text { paylaştırılamayacağının belirtilmesi. }\end{array}$ \\
& &
\end{tabular}

1

1
Çarpma ya da bölmedeki etkisiz elamanın 0 olarak 2 düşünülmesi. 12'nin sıfıra bölünemeyeceğinin sözel olarak ifade edilmesi.
$12 \div 0=x$ ifadesinin $\quad 12=0 . x$ ifadesine dönüştürülmesi ve denklem çözümünün yapılması.
Kural olarak algılama, ezbere düşünme.
1

1

Paydası 0 olan sayıların rasyonel olmayacağını belirtilmesi.

Tablo 3'den de anlaşılacağı üzere matematik öğretmenlerinden üçü aynı olası neden üzerinde durmuştur. Öğretmenlerden elde edilen çözüm önerileri incelendiğinde ise iki öğretmenin benzer cevap verdiği görülmektedir. Bununla birlikte hem olası nedenler hem de çözüm önerileri kategorisinde cevap veremeyen öğretmenler de bulunmaktadır. Aşağıda ikinci senaryo ile ilgili araştırmacı ve öğretmenler arasında geçen konuşmaların analizi sonucunda elde edilen bulgular, öğretmenlerin söylemlerinden doğrudan alıntılar da kullanılarak sunulmuştur.

Turgut, öğrencinin verdiği cevapta izlediği adımları tekrar ederek; "Hmm, ikinciyi ters çevirmiş çarpmış, payları çarpıp pay kısmına, paydaları çarpıp payda kısmına yazmış ve $12 \div 0$ elde etmiş. Bunu cevabına da 12 demiş." demiştir. Araştırmacı ise öğrencinin neden böyle düşündüğünü tekrar sormuştur. Bunun üzerine Turgut; "Ashında yapması gereken işlem; önce $0 \div 3$ ifadesine sıfır demeliydi. Oradan da $(4 \div 5) \div 0$ olurdu. Buradan sonra da normalde tanımsız demeliydi." diyerek öğrencinin aslında yapması gereken işlemleri ve vermesi gereken cevabı dile getirmiştir. Öğrencinin cevaba "tanımsız" demesi gerektiğini belirten Turgut araştırmacının sorusu üzerine tanımsızlık kavramına değinip değinmediğini; "Yok değinmiyoruz, ama "rasyonel 
değildir" kavramı var 7'lerde. Biz paydası 0 olan ifadelerin rasyonel olmayacă̆ını belirtiyoruz." sözleriyle açıklamıştır. Araştırmacı daha sonra; "Tamam hocam sorumuzun köküne dönecek olursak, öğrenci sıfira nasıl bir anlam yüklemiş olmalı ki sıfıra böldüğ̈̈ halde sonuç yine 12 olmuş olabilir sizce?" diyerek öğretmenin senaryoya tekrar odaklanmasını sağlamıştır. Bunun üzerine Turgut; "Hiçbir işlem yapmamış gibi, 12'yi hiç bölmemiş gibi düşünmüş sanki. Yani 12'yi sıfira bölmek 12 üzerinde hiçbir işlem yapmamak, 12 ye dokunmamak gibi düşünmüş bence." demiştir. İkinci kısımda ise araştırmacı, öğretmene böyle bir durumla karşılaşması halinde nasıl bir dönüt vereceğini sormuştur. Turgut ise öğrenciyi sıfıra bölemeyeceği konusunda nasıl ikna edeceğinden bahsederek; "Böyle durumlarda mesela bu soru için 12'nin neden sıfira bölünmediğini ben şöyle anlatıyorum. Diyelim ki olmayan bir şeyi mesela sıfır tane cevizi 2 kişi paylaşsa sıfır tane ceviz düşer ama 2 tane cevizi olmayan kişilere yani 0 kişiye paylaştıramadığımızı anlatıyorum. Kişi başı kaç ceviz düşer diye soramıyoruz çünkü ortada kişi yok. Yani bu şekilde somutlaştırarak anlatmaya çalışıyorum." demiştir.

Yukarıda sunulan mülakat sürecinden de anlaşıldığı gibi, Turgut ilk aşamada öğrencinin ne yaptığından ve ne yapması gerektiğinden bahsetmiş ancak neden böyle düşündüğü hakkında fikir beyan edememiştir. Ancak bir süre sonra öğrencinin sıfır sayısına nasıl bir anlam yükleyerek bu cevaba ulaştığı konusunda bir görüş belirtmiştir. Turgut, öğrencisine vereceği dönüt olarak da, 12'yi neden sıfıra bölemeyeceğini paylaştırmaya dayalı bölme kavramını kullanarak somut nesnelerle açıklayacă̆ını belirtmiştir.

Mehtap ise öğrencinin çözüm yolundaki adımları sesli düşünerek birkaç defa tekrar etmiştir. Öğretmenin herhangi bir açıllama yapmadığını ve düşünmek için zamana ihtiyacı olduğunu fark eden araştırmacı, öğretmeni rahatlatmak amacıyla daha önce böyle bir durumla karşı karşıya gelip gelmediğini sormuştur. Mehtap ise daha önce böyle düşünen bir öğrencisinin olmadığını belirtmiş ve biraz daha düşündükten sonra ise; "12'yi hiçbir şeye bölmüyoruz. O yüzden 12 alıyoruz diye düşünmüş olabilir. Kesir soruların daha çok pasta ekmek üzerinden anlatıyoruz. Ekmeği hiçbir şeye bölmezsen olduğu gibi kalıyor diyordur herhalde öğrenci. Ama soracağım ben bu soruyu öğrencilerime, merak ettim." demiştir. Araştırmacı, ikinci kısımda Mehtap'a böyle düşünen bir öğrencisinin olması halinde ona nasıl bir dönüt vereceğini sormuştur. Mehtap, öğrencisine bunun cevabını uzun uzun anlatmayacağını belirterek; "Aslında bu sorunun cevabinın ne olduğunu bilmiyoruz diyoruz burada. Üniversitelerde bize anlatıldığı gibi uzun uzadıya anlatmıyoruz." demiştir. Burada öğretmen üniversitede anlatılan yönteme değinmediği için, araştırmacı etik kaygilarla bu durum için ek bir soru yöneltmemiştir.

Yukarıdaki söylemlerden yansıdığı gibi, Mehtap ilk aşamada biraz düşünmüş sonrasında ise öğrencinin sıfır sayısına yüklediği anlamı belirterek bir olası neden belirtmiştir. Böyle bir durumla karşılaşması durumunda ise öğrencilere dönüt olarak, bu işlemin sonucunun bilinemeyeceğini ifade edeceğini söylemiş ve belki de kendisinin de zorlandığı için kaçamak bir cevap vererek detaylı bir şekilde anlatmaya gerek olmadığını belirtmiştir.

Zeliha ise öğrencinin düzeyinin önemli olduğuna dikkat çekerek, bu cevabı veren öğrencinin kaçıncı sınıfta olduğunun göz önüne alınarak değerlendirilmesi gerekeceğini belirtmiştir. Araştırmacının bu cevabı veren farklı sınıf seviyelerinde öğrencinin olması ile birlikte ağırlık olarak yedinci sınıf öğrencilerinin bu cevab1 verdiğini belirtmesi üzerine Zeliha; “Normalde bunu biliyor olması lazım. Öğrenci 
buradaki sıfırı sanki 1 gibi düşünmüş. Sanki çarpmada ya da bölmede etkisiz eleman olan 1 ile sıfırı karıştırmış gibi." demiştir. İkinci kısımda araştırmacının, böyle bir durumla karşılaşması halinde vereceği dönütü sorması üzerine Zeliha; "Biz böyle durumlarda öğrencilere çok açıklama yapmıyoruz, sadece bilgi olarak 12 sayısı 0'a bölünmez diyoruz. Bende böyle bir dönüt verirdim." diyerek bu söylemin ötesinde açılama yapmayacağını belirtmiştir.

Zeliha'nın bu ifadeleri öğrencinin neden böyle bir cevap verdiği konusunda olası bir neden belirttiğini ancak çözüm önerisi olarak öğrenciye bu işlemin bir kural olduğunu ve 12'nin sıfıra bölünmeyeceğini belirteceğini söylemekle yetindiğini göstermektedir.

Gül ve araştırmacı arasında bu senaryo ile ilgili geçen konuşmada Gül; öğrencinin verdiği cevapta olası bir neden olarak; "Şöyle düşünmüştür muhtemelen; 12'yi hiçbir şeye bölersen yine 12 olur. Mesela 12'yi 2 parçaya bölsem 6, 6 düşer ama hiç parçalamazsam olduğu gibi kalır diye algılıyor demek ki." ifadesini kullanmıştır. Araştırmacı öğretmenin farklı cevaplar da verebileceği ihtimaline karşın bir süre daha beklemiş ancak ögrretmenden farklı bir yorum gelmeyince öğretmenin öğrenciye verebileceği dönütü sormuştur. Bunun üzerine Gül; "Hocam öğrenci lise seviyesinde ise doğrudan tanımsız, belirsiz açıklaması yapardım. İşlemin sonucunu $x^{\prime} e$ eşitletirim mesela, içler dışlar çarpımı yaptırırım. Sonra; $12=0 . x$ işleminde sıfırı herhangi bir sayı ile çarpıp 12 bulabilir misin diye sorarım. Öğrenci de muhtemelen öyle bir sayı olmadiğını söyleyecek. Ama öğrenci lise seviyesinden küçük bir öğrenci ise, onu tam bilmiyorum şu an. Ama 12'yi sıfır kişiye paylaştıramayacağını belirtirim kesinlikle." diyerek öğrencinin bir çelişki elde etmesini sağlatacağını belirtmiştir.

Tüm bu söylemler, öğrencinin neden böyle düşündüğü konusunda Gül'ün bir fikrinin olduğunu ve bu durumun düzeltilmesi adına da öğrencilerin sınıf düzeyine göre bir çözüm önerisi ileri sürebildiğini yansıtmaktadır. Yine bu ifadeler, aynı zamanda öğretmenin tanımsız ve belirsiz kavramlarını eşanlamlı olarak değerlendirdiğini de yansıtmaktadır.

Emre ise mülakat sırasında, öğretmenlerin kesirlerde bölme işleminde öğrencilere yanlış kural öğrettiğini savunarak; "Bizim burada öğretmenler olarak yanlışımız şu oluyor o zaman; demek ki birinci kesri aynen yazıp ikinci kesri ters çevirip çarpmamak gerekiyor." demiştir. Araştırmacı ise öğretmenin farklı bir nokta üzerine odaklandığını fark etmesi üzerine; "Hocam şu kısma bakalım. Öğrenci 12'yi sıfıra bölüyor ve yine 12 buluyor. Bunun nedeni ne olabilir?" demiştir. Bunun üzerine Emre; "Ben de tam kestiremedim şimdi nedenini. Bunu çocuğa sormak lazım aslında. 12'yi 3'e bölsen, 3 kişiye dağıtırsın. 0 kişiye nasıl dağıttın? Ama tekrar söylüyorum şurada yapılan ters çevirip çarpma konusunda yanlış yapıyor olabiliriz." diyerek herhangi bir olası neden belirtememiştir. Araştırmacı ikinci kısımda öğretmene, öğrenciye nasıl bir dönüt vereceğini sormuştur. Ancak Emre, öğrenciye cevabın "tanımsız" olduğunu söylemek gerektiğini ancak bunu nasıl açıklayacağını bilmediğini belirtmiştir.

Yukarıdaki görüşler bir bütün olarak değerlendirildiğinde, Emre'nin öğrencinin neden böyle bir cevap verdiği hakkında ve bu cevabı veren öğrenciye verilebilecek dönüt konusunda net bir görüşe sahip olmadığ1 söylenebilir.

Ahmet ve araştırmacı arasında bu senaryo ile ilgili geçen konuşmada ise Ahmet, öğrencinin bu cevabı verirken sifır sayısına herhangi bir anlam yüklemediğini belirterek; "Bence doğrudan kural gibi düşünmüş, sıfır demiş. Sıfıra bir mana yüklememiş, yorum yapmamış yani." demiştir. Öğretmenin söyleyeceği farklı bir 
şey olmadığı anlaşıldığında diğer soruya, yani öğretmenin böyle düşünen bir öğrenciye verebileceği dönütün ne olabileceği sorusuna geçilmiştir. Bu kısımda ise Ahmet, çözüm önerisinin ne olduğunu; "Eksik olan bilgiyi verirdim, sayı $\div 0$ 'in sayıya eşit olmayacağını belirtirim. Tanımsız, belirsiz derim." ifadelerini kullanarak açıklamıştır.

Yukarıdaki söylemlerden de anlaşıldığı gibi, Ahmet öğrencinin cevabının herhangi bir olası nedenini belirtememiş ve böyle düşünen bir öğrencisinin olması halinde bu durumun düzelmesi için kuralı ifade etmek dışında herhangi bir çözüm önerisi geliştirememiştir. Yine Ahmet'in bu ifadelerinde tanımsız ve belirsiz kavramlarını eşanlamlı olarak kullandığı da görülmektedir.

\section{Tartışma, Sonuç ve Öneriler}

$\mathrm{Bu}$ çalışmada elde edilen bulgular, genel olarak öğretmenlerin sıfır kavramıyla ilgili öğrenci anlayışlarını belirleyebildiklerini ve bu anlayışların nedenlerini farklı açılardan yorumlayabildiklerini fakat öğrenci zorluklarının ve kavram yanılgılarının giderilmesine yönelik çözüm önerileri geliştirirken zorlandıklarını ortaya çıkarmıştır. Bu sonuç, Gökkurt, Şahin ve Soylu (2016), Mumcu (2017) ve Gökbulut'un (2010) çalışmalarında elde edilen sonuçlarla da desteklenmektedir. Ayrıca, Tükenmez (2014), öğrencilerin yaşadığı kavramsal zorlukları veya yanılgıları belirleme noktasında başarılı olan öğretmenlerin her ne kadar derslerde anlaşılmayan konu ve kavramları bazı yöntemler kullanarak anlaşılır hale getirdiklerini düşünseler de bu yanılgıları giderici öneriler getirme boyutunda yetersiz kaldıklarını belirtmiştir. Bununla birlikte, ilköğretim matematik öğretmenlerinin ortaöğretim matematik öğretmenlerine göre öğrencilerin sıfır kavramıyla ilgili anlayışları hakkında daha fazla ve farklı görüşler beyan ettikleri ortaya çıkmıştır. Senaryoların matematiksel içeriğinin ortaokul matematiğine daha yakın olması ve ilköğretim matematik öğretmenlerinin senaryolardakine benzer durumlara sınıflarında da karşılaşmış olmaları ihtimali bu durumun sebepleri arasında gösterilebilir.

Öğretmenlerle yapılan görüşmelerin detayları incelendiğinde ise bazı öğretmenlerin öğrencilerin yaşadıkları zorlukları gidermeye yönelik çözüm önerilerinde, doğru cevabı kurallara vurgu yaparak doğrudan açıklama girişiminde oldukları ortaya çıkmıştır. Bu yöntemin tercih edilmesinde öğretmenlerin kendi alan bilgilerinin sınırlayıcı bir etkisi olduğu söylenebilir. Konuyla ilgili birçok çalışmada da vurgulandığı gibi, öğretmenler bir konunun ya da kavramin öğretiminde ancak kendi alan bilgilerinin derinliği ölçüsünde farklı yöntemler önerebilmektedir (Ma, 1999; An, 2004; Bütün, 2005). Bunun yanında öğretmenlerin matematik bilgilerinin derinliği öğretim yaklaşımlarındaki çeşitliliği ve zenginliği açıklamada her zaman tek başına yeterli olamamaktadır. Örneğin Emre öğretmenin mülakattaki söylemleri, tek ve çift sayılarla ilgili kendisinin kısmen olgun sayılabilecek anlayışının öğrencinin yaşadığ1 zorluğu çözemeye yönelik önerdiği yöntemlere yeterince yansımadığını göstermektedir. Yine çalışmada bazı öğretmenlerin senaryolarda sunulan öğrencilerin zorluk ve yanılgılarını dikkate almadan kavramı ya da konuyu yeniden anlatma/tekrar anlatma girişiminde bulundukları ortaya çıkmıştır. Bu durum; yani öğretmenlerin öğrencilerdeki kavram yanılgılarıyla karşılaşmaları halinde, bu yanılgılara özel herhangi bir çözüm önerisi geliştirmektense, bunları görmezden gelip konuyu/kavramı öğrenciye yeniden anlatması ve göstermesi Chick ve Baker (2005) ile Son'un (2013) çalışmalarındaki katılımcılarda da gözlemlenmiştir. Benzer olarak Bütün (2005), bazı öğretmenlerin senaryolardaki öğrencilerde bulunan 
kavram yanılgılarını gidermeye ilişkin açıklama yapmak yerine konuyu sınıfta nasıl anlattığından bahsettiğini belirtmektedir. Bir öğretmenin konu ya da kavramın özel bir yönü ile ilgili öğrencilerin yaşadıkları zorlukların üstesinden gelirken o konuyu "sil baştan" yeniden öğretmeye yönelmesi, ya öğrencinin düşüncesini yeterince anlamadığının ya da anlasa da sorunlu noktaya özel bir çözüm üretemediğinin yansıması olarak değerlendirilebilir.

Bu çalışmada ortaya çıkan diğer bir sonuç ise, öğrencilerin yaptıkları hataların düzeltilmesine yönelik öğretmenlerin pedagojik yaklaşımlarının senaryolar arasında farklılaşması, aynı senaryo içerisinde ise benzerlik göstermesidir. İlk senaryoda iki ortaöğretim matematik öğretmeni hariç diğer tüm öğretmenler örüntü oluşturma ve bilişsel çelişki yöntemleriyle öğrencinin yaptığı hatayı fark etmelerini sağlayabileceklerini ifade ederken, ikinci senaryoda tüm öğretmenler öğrencinin hatasını genellikle kural odaklı açıklamaları kullanarak doğrudan anlatma/gösterme yaklaşımı ile düzeltebileceklerini belirtmişlerdir. İkinci senaryonun matematiksel içeriğinin ilkine göre öğretmenleri daha zorlayıcı olması, bu farklılığın ortaya çıkmasının bir nedeni olarak gösterilebilir. Sıfıra bölme konusunun ele alındığ birçok çalışmada da öğretmen ve öğretmen adaylarının matematik bilgilerinin niteliklerinin yeterli düzeyde olmadığ1 ve bu durumun öğretme bilgilerini de sinırlandırdığı belirtilmektedir (Bütün, 2005, 2012; Cankoy, 2010; Karakuş, 2017; Quinn, Lamberg ve Perrin, 2008). Diğer yandan senaryolara verilen cevaplar öğretmenlerin matematik bilgilerinin başka sorunlu noktalarını da açığa çıkarmıştır.

Bunlardan ilki, negatif tamsayılarda çiftlik ve tekliğin sorgulanamayacağına ilişkin düşüncedir. İkincisi, sıfıra bölme ile ilgili açıklamalarda tanımsız ve belirsiz kavramlarının eş anlamlı olarak kullanılmasıdır. Üçüncüsü ise öğretmenlerin bölme kavramı ile ilgili anlayışlarının çoğunlukla bölmenin paylaştırma anlamıyla sınırlı olmasıdır. İkinci ve üçüncü yöndeki anlayışlara öğretmen ve öğretmen adaylarıyla yürütülen farklı çalışmalarda da rastlanmışır (Ball, 1990; Bütün, 2012; Crespo ve Nicol, 2006; Çelik ve Akşan, 2013; Even ve Tirosh, 1995; Karakuş 2017). Öğretmenlerin bölme kavramı ile ilgili bilgilerinin bölmenin eşit paylaştırma anlamıyla sınırlı olması, senaryodaki öğrencinin hatasını düzeltmeye yönelik geliştirdikleri örnekleri, açıklamaları ya da problemleri sınırlandırmış olabilir. Örneğin, Turgut öğretmenin 12 cevizi 0 öğrenciye eşit paylaştırma probleminin, senaryodaki öğrencinin yanılgısını devam ettirme/destekleme potansiyeli bulunmaktadır. Yani, öğrenci söz konusu paylaştırmayı yapamayacağı için bölünen sayının aynen kalacağını, dolayısıyla işlemin sonucu olarak 12 sayısının elde edileceğini düşünebilir. Bu nedenle öğrenciye sunulacak örnekler, öğrencinin sınıf seviyesi de dikkate alınarak, bölme kavramının farklı anlamlarını da içerecek şekilde zenginleştirilmelidir. Bölmenin farklı anlamlarını yansıtan (örneğin, geriye doğru çıkarma ya da ölçme anlamı) somut gösterimler ya da açıklamaların yanında soyut (formal) gösterimlerin de kullanılması (Tsamir ve Sheffer, 2000) öğrencilerin her matematiksel işlemin bir sonucu olması gerektiğine ilişkin kökleşmiş inanışlarını da gözden geçirmelerini sağlayacaktır (Tsamir, Sheffer ve Tirosh, 2000). Ayrıca, somut günlük yaşam durumlarına dayalı açıklamaların her ne kadar öğrencilerin anlamasını kolaylaştırdığı düşünülse de, sonraki öğrenmelerini zorlaştırabileceği de gözden kaçırılmamalıdır. Bir kavramı ya da işlemi temsil eden belirli bir model özellikle erken yaşlarda somutluğu nedeniyle çok yararlı olsa da, sonraki yıllarda 
çocuğun aynı kavramın daha genel ve daha soyut yorumlarına geçiş yapmasını imkânsız hale getirebilir (Fischbein, 1987). Örneğin, bu çalışmada bazı öğretmenlerin sıfıra bölmeyi somutlaştırırken sıfırı "olmayan şey" ya da "hiçlikle" özdeşleştirmeleri, sıfırın bölünemeyeceği yönünde bir anlayışı da doğurabilir, çünkü öğrenciye göre ortada bölünebilecek, parçalara ayırılabilecek bir "şey" bulunmamaktadır. Yine buradan hareketle, öğrenci sıfırın ikiye bölünemeyeceğini düşünerek, hatalı bir şekilde sıfır sayısı ne çift ne de tektir diyebilmektedir (Levenson, Tsamir ve Tirosh, 2007). Bu nedenle, öğretmenler öğrencilerini yönlendirirken, hatalarını düzeltirken, onlara dönütler verirken "bir yeri yaparken, diğer yeri yıkma" potansiyelini her zaman göz önünde bulundurmalıdır. İyi öğretmenler öğrencilerin düşünme biçimlerini ve önceki öğrenmelerinin mevcut ve sonraki öğrenmelerini nasıl etkileyebileceğini bilir. Öğrencilerin konu, kavram ve işlem yolları ile ilgili nerelerde, nasıl hatalar yapabileceklerini öngörür ve gerektiğinde bu hataları bir öğrenme fırsatına dönüştürebilir. Bu çerçevedeki öğretmen yeterlikleri öğretmenlerin alanı öğretme bilgilerinin önemli bir öğesi olarak öğrenciyi tanıma bilgilerinin niteliklerinin geliştirilmesi ile mümkün olacaktır. Bu amaca yönelik hizmet-içi eğitim uygulamalarında kısa süreli bilgi aktarımına dayalı seminerlerden ziyade ders imecesi gibi öğrenci düşüncesine odaklanan mesleki gelişim modellerinin kullanılması önerilebilir (Bütün, 2015).

$\mathrm{Bu}$ araştırmada elde edilen sonuçların yalnızca öğretmenlerle gerçekleştirilen mülakatlara dayanması çalışmanın bir sınırlılığı olarak değerlendirilebilir. Her ne kadar senaryolarda işlenen özel durumlarla birebir aynı durumların gerçek sınıflarda yakalanması güç olsa da, ilerideki araştırmalarda sınıf ortamlarında uzun süreli gözlemler yapılarak öğretmenlerin benzer durumlarda hangi yaklaşımları kullandıkları incelenebilir. Bu çalışmaya katılan 6 öğretmenin hizmet süreleri 4 ile 8 yıl arasında değişmekteydi. Sonraki araştırmalarda öğrenciyi tanıma bilgisi ile ilgili daha farklı hizmet sürelerine sahip matematik öğretmenleriyle çalışılarak, karşılaştırmalar yapılabilir. Öğretmenlerin öğrenci hatalarına verdikleri dönütler ve bu hataları düzeltme biçimleri bilgilerinin yanında inanışlarının da etkisindedir (Bütün, 2012). Örneğin, sıfıra bölmenin tanımsızlığını gerekçelendirerek açıklayabilen bir öğretmen, hata yapan öğrenciye dönütünde sadece tanımsız olduğunu söylemekle yetinebilir. Bu durumda, öğretmenin öğrencinin neyi ne kadar öğrenmesi gerektiğine ilişkin inancının yanı sıra, kendi rolüne ilişkin inanışları da etkili olabilir. Bu nedenle öğretmenlerin benimsedikleri yöntemlerin bilgi penceresi yanında inanç perspektifi ile de ele alınması, matematik öğretmenlerinin yeterlikleri ile ilgili resmin bütününü görmemize yardımcı olacaktır.

\section{Kaynakça}

Altoğ, Ö. (2016). Ankara İli Yeni Mahalle İlçesi 8. Sınıf Öğrencilerinin Matematik Öğreniminde Bazı Matematik Konularında Sıfır ile İlgili Hata ve Kavram Yanılgıları. (Yayınlanmamış yüksek lisans tezi), Gazi Üniversitesi Eğitim Bilimleri Enstitüsü, Ankara.

An, S. (2004). The Middle Path in Math Instruction: Solutions for Improving Math Education. Rowman and Littlefield Publishing Group, 4501 Forbes Blvd., Suite 200, Lanham, MD 20706.

Anthony, G. J. and Walshaw, M. A. (2004). Zero: a "none" number?. Teaching Children Mathematics, 11(1), 38-43. 
Ball, D. L. (1990). Prospective elementary and secondary teachers' understanding of division. Journal for Reseach in Mathematics Education, 21(2), 132-144. https:// doi.org/10.2307/749140

Bütün, M. (2005). İlköğretim matematik öğretmenlerinin alan eğitimi bilgilerinin nitelikleri üzerine bir çalışma. (Yayınlanmamış yüksek lisans tezi), Karadeniz Teknik Üniversitesi Eğitim Bilimleri Enstitüsü, Trabzon.

Bütün, M. (2011). Matematik öğretmenlerinin alan eğitimi bilgi yapılarının incelenmesinde senaryo tipi mülakat sorularının kullanımı. Dicle Üniversitesi Ziya Gökalp Ĕ̆itim Fakültesi, (16), 105- 115.

Bütün, M. (2012). İlköğretim matematik öğretmeni adaylarının uygulanan zenginleştirilmiş program sürecinde matematiği öğretme bilgilerinin gelişimi. (Yayınlanmamış doktora tezi), Karadeniz Teknik Üniversitesi Eğitim Bilimleri Enstitüsü, TRABZON.

Bütün, M. (2015). Öğretmenlik Uygulaması Dersinde Ders İmecesi Modelinin Değerlendirilmesi: Sorunlar ve Çözüm Önerileri. Adıyaman Üniversitesi Ĕ̆itim Bilimleri Dergisi, 5(2), 136-167. https:/ / doi.org/10.17984/adyuebd.07565

Boyer, C. B. (1944). Zero: The symbol, the concept, the number. National Mathematics Magazine, 18(8), 323-330.

Cankoy, O. (2010). Matematik öğretmenlerinin a0, 0! ve a $\div 0$ ile ilgili konu temelli pedagojik alan bilgileri. Kuram ve Uygulamada Ĕ̆itim Bilimleri, 10 (2), 729-769.

Chick, H. L. ve Baker, M. K. (2005). Investigating teacher's responses to student misconceptions. In H. L. Chick and J. L. Vincent (Eds.). Proceedings of the 29th Conference of the International Group for the Psychology of Mathematics Education (Vol.2, pp. 249-256). Melbourne, Victoria, Australia: PME.

Cockburn, A.D. ve Parslow-Williams, P. (2008). Zero,Understanding an apparently paradoxicalnumber, Cockburn, A. D., Littler, G.(Eds.), Mathematical misconceptions (s. 7-22). London: Sage. https:/ / doi.org/10.4135/9781446269121.n2

Crespo, S. ve Nicol, C. (2006). Challenging preservice teachers' mathematical understanding: The case of division by zero. School science and mathematics, 106 (2), 84-97. https:// doi.org/10.1111/j.1949-8594.2006.tb18138.x

Creswell, J. W. (2018). Nitel araştırma yöntemleri (Bütün M, Demir SB, Çev. Ed.). Ankara: Siyasal Kitabevi.

Çelik, D. ve Akşan, E . (2013). Matematik öğretmeni adaylarının sonsuzluk, belirsizlik ve tanımsızlık kavramlarına ilişkin anlamaları. Necatibey Ĕgitim Fakültesi Elektronik Fen ve Matematik Eğitimi Dergisi, 7(1), 166-190. DOI: $10.12973 /$ nefmed158.

Darling-Hammond, L. (2000). Teacher quality and student achievement. Education policy analysis archives, 8, 1. https:/ / doi.org/10.14507/epaa.v8n1.2000

Even, R. ve Tirosh, D. (1995). Subject-matter knowledge and knowledge about students as sources of teacher presentations of the subject-matter. Educational Studies in Mathematics, 29, 1-20. https:/ / doi.org/10.1007/BF01273897

Fischbein, E. (1987). Intuition in science and mathematics. Dordrecht, the Netherlands: Reidel Publishing Company. 
Gökbulut, Y. (2010). Sını Öğretmeni Adaylarının Geometrik Cisimler Konusundaki Pedagojik Alan Bilgileri. (Yayınlanmamış doktora tezi), Gazi Üniversitesi Eğitim Bilimleri Enstitüsü, Ankara.

Gökkurt, B., Şahin, Ö. ve Soylu, Y. (2016). Öğretmen adaylarının değişken kavramına yönelik pedagojik alan bilgilerinin öğrenci hataları bağlamında incelenmesi. Pamukkale Üniversitesi Ĕ̆itim Fakültesi Dergisi, 39(39), 17-31. https:/ / doi.org/10.9779/PUJE658

Grossman, P. L. (1990). The making of a teacher: Teacher knowledge and teacher education. Teachers College Press, Teachers College, Columbia University.

Henry, B. (1969). Zero, the troublemaker. The Arithmetic Teacher, 16 (5), 365-367. Hill, H. C., Ball, D. L. ve Schilling, S. G. (2008). Unpacking Pedagogical Content Knowledge: Conceptualizing and Measuring Teachers' Topic-Specific Knowledge of Students. Journal for Research in Mathematics Education, 39, 372400.

Ifrah, G. (1985). Rakamların evrensel tarihi v : sıfırın gücü. (K. Dinçer, Ed.). 5. Baskı. İstanbul: TÜBİTAK.

İşgüden, E. (2008). 7. ve 8. sını öğrencilerinin tamsayılar konusunda karşılaştıkları güçlükler. (Yayınlanmamış yüksek lisans tezi). Eskişehir Osmangazi Üniversitesi, Eskişehir.

Jing-Jing, H. (2014). A critical review of pedagogical content knowledge' components: Nature, principle and trend. International Journal of Education and Research, 2, 411-424.

Kaplan, R. (1999). The nothing that is:a natural history of zero. New York: Oxford University.

Karakuş, F. (2017). İlköğretim matematik öğretmeni adaylarının öğretimsel açıklamalara ilişkin tercihleri: Sıfıra bölme konusu. Türk Bilgisayar ve Matematik Ĕ̈itimi Dergisi, 8(3), 352-377.

Levenson, E., Tsamir, P. ve Tirosh, D. (2007). First and Second Graders Use of Mathematically-based and Practically-based Explanations for Multiplications with Zero. Focus on Learning Problems in Mathematics, 29(2), 21.

Ma, L. (1999). Knowing and Teaching Elementary Mathematics: Teachers' Understanding of Fundamental Mathematics in China and the United States, Mahwah, NJ, Lawrence Erlbaum.

Marks, R. (1990). Pedagogical content knowledge: From a mathematical case to a modified conception. Journal of Teacher Education, 41 (3), 3-11. https:// doi.org/10.1177/002248719004100302

Mumcu, H.Y. (2017). Pedagojik alan bilgisi bağlamında öğretmen adaylarının kesirlerle ilgili kavram yanılgılarını giderme yeterliklerinin farklı değişkenlere göre incelenmesi. Bartın Üniversitesi Ĕ̆itim Fakültesi Dergisi, 6(3), 1264-1292. https:// doi.org/10.14686/buefad.337019

Kumtepe, E. G. (2011). Okulöncesinde Matematiksel Kavramlar ve Etkinlikler II. A. Özdaş (Ed), Okulöncesinde Matematik Eğitimi (s. 145-169) içinde. Eskişehir: Anadolu Üniversitesi Yayınları.

Quinn, J. R., Lamberg, T. D. ve Perrin, J. R. (2008). Teacher perceptions of division by zero. The Clearing House, 81(3), 101-104. https:// doi.org/10.3200/TCHS.81.3.101-104 
Sharma M. C. (1993). Place value concept: how children learn it and how to teach it. Math Notebook, 10(1-2), 1-26.

Shulman, L. S. (1986). Those who understand; knowledge growth in teaching. Educational Researcher, 15(2), 4-14. https:// doi.org/10.3102/0013189X015002004

Shulman, L. S. (1987). Knowlegde and teaching: Foundations of the new reform. Harvard Educational Review, 57(1), 61-77. https:/ / doi.org/10.17763/haer.57.1.j463w79r56455411

Son, J. W. (2013). How preservice teachers interpret and respond to student errors: Ratio and proportion in similar rectangles. Educational Studies in Mathematics, 84(1), 49-70. https://doi.org/10.1007/s10649-013-9475-5

Tanışlı, D. (2013). İlköğretim matematik öğretmeni adaylarının pedagojik alan bilgisi bağlamında sorgulama becerileri ve öğrenci bilgileri. Eğitim ve Bilim, 38 (169), 80-95.

Tsamir, P. ve Sheffer, R. (2000). Concrete and formal arguments: The case of division by zero. Mathematics Education Research Journal, 12(2), 92-106. https:// doi.org/10.1007/BF03217078

Tsamir, P., Sheffer, R. ve Tirosh, D.(2000). Intuitions and Undefined operations: The Cases of Division by Zero. Focus on Learning in Mathematics, 22(1), 1-16.

Tsamir, P. ve Tirosh, D. (2002). Intuitive beliefs, formal definitions and undefined operations: Cases of division by zero. In Beliefs: A hidden variable in mathematics education? (pp. 331-344). Springer, Dordrecht. https:/ / doi.org/10.1007/0-30647958-3_19

Tükenmez, S. (2014). Illköğretim matematik öğretmenlerinin farklı hizmet sürelerine sahip olma durumlarına göre pedagojik alan bilgilerinin incelenmesi. (Yayınlanmamış doktora tezi). Marmara Üniversitesi Eğitim Bilimleri Enstitüsü, İstanbul.

\section{Summary}

\section{Introduction}

Zero, which has different properties from other numbers, is of great importance in the development of the number concept. In the literature, it is stated that there are various mathematical difficulties in students' concept of zero in educational research (Henry, 1969; Anthony ve Walshaw, 2004; Levenson, Tsamir ve Tirosh, 2007). The responsibility of developing suggestions for the solution of the difficulties of the students belongs to the teachers. Therefore, the quality of teachers directly affects the quality of teaching (Darling-Hammond, 2000). Teachers' knowledge of students is the knowledge about students' prior knowledge, misconceptions, difficulties and learning methods (An, 2004). This knowledge is quite effective on the teaching decisions of teacher in the classroom (Tanisli, 2013).

In the literature, the characteristics of teachers and prospective teachers' knowledge about the concept of zero has been reported in various studies (Henry, 1969; Anthony ve Walshaw, 2004; Levenson, Tsamir ve Tirosh, 2007). The focus of these studies and their results are mostly on the qualities of the mathematics teachers' knowledge of the zero concept. Content knowledge alone is not sufficient to explain the quality of the teacher's knowledge. It is also necessary to examine what 
teachers know about students' knowledge of the concept of zero. Thus, in addition to the content knowledge of the teachers, this study will be able to draw conclusions about the quality of the pedagogical content knowledge. In addition, these results will help both to evaluate the approaches to train mathematics teachers and to review the resources and materials related to teaching the concept.

The aim of this study is to examine the knowledge of mathematics teachers about the causes of difficulties in the concept of zero and suggestions of solutions to overcome these difficulties.

\section{Method}

Qualitative case study method was used in this research. The participants of the study consisted of a total of 6 mathematics teachers, 3 middle school and 3 high school mathematics teachers. In this research, two scenario-type interview questions related to the concept of zero were used. The first one of these questions is about the opinion of a group of students who do not accept zero as an odd or even number, and the other one is about a student's erroneous solution in division including the number zero. In the interviews, at the first stage, teachers were asked to explain how / why students in scenarios might have thought so. In the second stage, the teachers explained how to give feedback to the students and how to overcome such difficulties. Data analysis took place in two stages. In the first stage, all the interview recordings were written and transferred to the computer. In the second stage, these data were examined for the purpose of the research, in the context of the possible causes of students' misconceptions and what the teachers' solution suggestions were, and they were also classified according to their similarities and differences. This classification was realized by coding, categorizing and accessing themes using the constant comparison method. While presenting the results of the research, tables indicating how many teachers were included in these themes for each scenario were organized and direct quotations were used to reflect the teachers' discourses about these themes that emerged when necessary.

\section{Results}

In the first scenario, three middle school mathematics teachers and two high school mathematics teachers expressed their opinions about the reasons for students' thoughts. The other teacher could not get an idea about why students think so. With the researcher's deepening question, this teacher stated that mathematics teachers in middle school might have started from 2 while describing even numbers. Five different answers were received from 6 teachers on the possible causes of student thinking, while 3 answers were received on solution suggestions. This shows that teachers' level of awareness about the causes of children's thoughts is more advanced than the solution suggestion levels. Findings revealed that teachers also had deficiency in their own mathematics knowledge about the concept of zero. For example, Zeliha teacher stated that the concepts of odd and even in negative numbers are not defined. She also claimed that these concepts should only be valid in natural numbers.

In the second scenario, when the data obtained from the interviews were examined, it was revealed that two of the three middle school mathematics teachers and one of the three high school mathematics teachers gave the same answer. These 
teachers stated that while the students divide 12 by zero, they might have thought that the number 12 remained as it was. The other middle school mathematics teacher stated that the students may have confused the number 1, which is the identity element in multiplication, and the number 0 . Two other high school mathematics teachers could not express their opinions about students' thoughts. One of these two teachers could not answer at all, and the other said that the students could not logically understand this operation and that they gave the recite answer. It was also revealed that the teachers adopted approaches such as creating problems, making formal explanations and saying the rule without giving a reason, by using the sharing model of the division with the help of concrete models in their feedbacks towards correcting student error. One of the teachers participating in the study used synonyms of "undefined" and "indeterminate" in their explanations.

\section{Discussion and Conclusion}

The results obtained in this study revealed that teachers in general can determine students' understandings about the concept of zero and they can interpret the reasons of these understandings from different perspectives, but they have difficulties in proposing solutions for students' difficulties and misconceptions. However, in this study, it was revealed that middle school mathematics teachers expressed more and different opinions about the students' understanding of the concept of zero than high school mathematics teachers. One of the reasons for this situation is that the mathematical content of the scenarios is closer to middle school mathematics teachers and that middle school mathematics teachers encountered similar situations in the classroom as well.

When the details of the interviews with the teachers were examined, it was revealed that some teachers attempted to explain the correct answer directly by emphasizing the rules in their propositions to solve the difficulties experienced by the students. It can be said that teachers' own mathematical knowledge has a limited effect on the selection of this method. As emphasized in many studies, teachers can suggest different methods of teaching a subject or concept. These suggestions are only within the scope of their content knowledge. (An, 2004; Bütün, 2005; Ma, 1999). In the study, it was revealed that some teachers attempted to re-explain the concept or subject without considering the difficulties and errors of the students presented in the scenarios. This is also observed in the participants of Chick and Baker (2005) and Son's (2013) studies, that if teachers encounter misconceptions in students answers, instead of ignoring them and they might develop a specific solution proposal for these misconceptions. It can be considered as a limitation of the study that the results obtained in this research are based only on interviews with teachers. Although it is difficult to catch the same situations exactly in the real class with the special situations handled in the scenarios; in the future researches, it can be examined what approaches teachers use in similar situations by making long-term observations in classroom settings.

\section{Araştırmanın Etik Taahhüt Metni}

Yapılan bu çalışmada bilimsel, etik ve alıntı kurallarına uyulduğu; toplanan veriler üzerinde herhangi bir tahrifatın yapılmadığı, karşılaşılacak tüm etik ihlallerde "Cumhuriyet Uluslararası Eğitim Dergisi ve Editörünün" hiçbir sorumluluğunun 
olmadığ1, tüm sorumluluğun Sorumlu Yazara ait olduğu ve bu çalışmanın herhangi başka bir akademik yayın ortamına değerlendirme için gönderilmemiş olduğu sorumlu yazar tarafından taahhüt edilmiştir.

\section{Authors' Biodata/ Yazar Bilgileri}

Mesut BÜTÜN Cumhuriyet Üniversitesi Eğitim Fakültesi'nde doktor öğretim üyesi olarak görev yapmaktadır. Doktorasını Karadeniz Teknik Üniversitesi Eğitim Bilimleri Enstitüsü'nde tamamlamıştır. İlgi duyduğu çalışma konuları öğretmen eğitimi, alanı öğretme bilgisi ve ders imecesidir.

Mesut Bütün is an assistant professor in Education Faculty of Cumhuriyet University, Sivas, Turkey. He completed his doctoral degree at Educational Sciences Institute of Karadeniz Technical University, Turkey. His research interests include mathematics teacher education and lesson study.

Naim ERDOĞAN Milli Eğitim Bakanlığı'nda matematik öğretmeni olarak çalışmaktadır. Sivas Cumhuriyet Üniversitesi Eğitim Bilimleri Enstitüsü'nde Yüksek Lisans Tez çalışmasını tamamlamıştır.

Naim Erdoğan is a mathematics teacher at Ministry of National Education of Turkey. He completed his Master's thesis in the Institute of Educational Sciences, Sivas Cumhuriyet University, Sivas. 